IJOTL TL, Vol. 5, No. 1, January 2020

p ISSN: 2502 2326; e ISSN: 2502 8278

Https://soloclcs.org; Email: ijolt1@gmail.com

Center of Language and Cultural Studies, Surakarta, Indonesia

Madayani, Soengkono, Nany \& Muhassin. 2020. Exploring Perception of EFL Teachers

towards the Use of Media in Teaching English.

IJOTL TL (2020), 5(1): 29 44. DOI: 10.30957/ijotl tl.v5i1.613.

\title{
Exploring Perception of EFL Teachers towards Use of Media in Teaching English
}

\author{
${ }^{1}$ Nany Soengkono Madayani \& ${ }^{1}$ Muhassin \\ English Department of Post Graduated Program, \\ State Islamic Institute (IAIN) of Tulungagung Indonesia \\ Corresponding Email: ${ }^{1}$ nanysoengkono@gmail.com
}

\begin{abstract}
This Research is against the backdrop of demand in mastering English. EFL teacher becomes one of main important part in teaching learning English to handle a certain role to maximal the students' achievement. The students' achievement here means not only someone that has a lot of knowledge and high value but also someone that can give positive contribution for other people. Because of that, the teachers have big responsibility to facilitate students in learning. One of the facilitation of teaching learning that has to be prepared by teachers is media. This study aims to investigate the teachers' perceptions of ELT media. This study is classified into three main dimensions of perception proposed by Vernon (1987) namely understanding, outlook and action. By conducting a survey study, the researcher collected, analyzed, elaborated and eventually drew conclusion dealing with the teachers' perceptions of ELT media. The main data of this study were collected with a interview and a questionnaire, which was distributed to 29 English teachers in the city of Tulungagung. The findings showed that Media is able to be benefit for both teachers and students, be applicable for every class. To select criteria of Media is based on Media Mastery or flexibility due to different reference and less facility. Besides that, The teachers have positive responses towards the two of the dimensions, understanding and view. The teachers however, do not show positive responses toward the action. However, in general, the English teachers' perceptions of ELT media in this study were categorized as a good perception. In other words, all the teachers have a positive perception of ELT media.
\end{abstract}

Keyword - EFL teacher, Perception, and Media. .

\section{INTRODUCTION}

Education is an effort planned to influence someone else for individuality and society, so that they can hope what the educators do (Soekidjo: 2003). Sedarmayanti (2001) said that education can make someone to have a provision to know, understand and develop a thinking method systematically in order to solve the problem will be. Soedijarto (1991) claimed that there are some points engaging the low quality of 
IJOTL TL, Vol. 5, No. 1, January 2020

p ISSN: 2502 2326; e ISSN: 2502 8278

Https://soloclcs.org; Email: ijolt1@gmail.com

Center of Language and Cultural Studies, Surakarta, Indonesia

Madayani, Soengkono, Nany \& Muhassin. 2020. Exploring Perception of EFL Teachers

towards the Use of Media in Teaching English.

IJOTL TL (2020), 5(1): 29 44. DOI: 10.30957/ijotl tl.v5i1.613.

education such as less giving role of each teacher, less planning, less action, bad management of curriculum, and the system of evaluations that is not used as education tool and integrated curriculum system. Soko (2017) said that excellent achievement of learning is able to be attained by the teachers' sterling material provision and seen with the activity of teaching-learning in the class running well. Ali (2005) claimed that there were two components to subscribe the triumphant acquiring of knowledge, those were teaching material and instructional media. The researcher here focuses in the instructional media in English.

The urgency of English in Indonesia especially in education becomes the common issues by educators. To learn or teach it is not easy to be done in as much as English is the foreign language for nations of Indonesia. Harsono (2006) said that English has some functions like developing the state and nation and building the relationship with other nations. There are four skills that have to be mastered in school for instance Listening, Speaking, Reading and Writing. According to Soko (2017), the complications found repeatedly in education are isolated into three categories such as input, process and output. Students are expected to pass standard competence and basic competence from teachers' lesson plan, and students are hoped to be able to at least practice confidently those four aspects in daily activity of students at home or school. Hence, the closure based the brief explanation above is Input from this case like the teachers, students and lesson plan, Process from this case like teaching learning activity of English, and the Output from this case is like student's achievement.

There are also some opinions of the previous researchers about media in teaching learning. The example is like Taiwo (2002). Taiwo took a study about the role of media in classroom. He said that two media roles were selected for the study: media used to supplement the teacher by enhancing his effectiveness in the classroom and media used to substitute the teacher through instructional media system. Other researcher is Rugut and Role (2013). They conducted the research about the Utilization of Educational Media in Teaching and Learning History and Government in Secondary Schools in Kenya. Their study recommends that teachers should go for in-service training to be acquainted with new educational media resources.

Teachers should also work closely with students when designing, improvising and utilizing educational media resources in teaching and learning in schools. The next researcher is Romiszowski (1998) discussing the Selection and use of Instructional Media. He said that the first instance media are used as instructional aids; here media are used exclusively to enhance or enrich the teacher's presentation.

That is one of reasons why the researcher wants to conduct the research about the media usage. Based on the fact and the finding of study above, Media becomes the most recommendation of teachers to be used. The researcher here wants to dig out the EFL teachers' perception about media. Therefore, What EFL teachers understand about the media usage, what EFL teachers believe about the media usage and how EFL teachers use the media in teaching learning activity is the research focus of this study.

\section{METHODS}


IJOTL TL, Vol. 5, No. 1, January 2020

p ISSN: 2502 2326; e ISSN: 2502 8278

Https://soloclcs.org; Email: ijolt1@gmail.com

Center of Language and Cultural Studies, Surakarta, Indonesia

Madayani, Soengkono, Nany \& Muhassin. 2020. Exploring Perception of EFL Teachers

towards the Use of Media in Teaching English.

IJOTL TL (2020), 5(1): 29 44. DOI: 10.30957/ijotl fl.v5i1.613.

This study conducted qualitative research method which was intended to gain the EFL teachers' perception toward media usage in teaching English. The study used a survey design. It is appropriate design to be conducted in this research due to the fact that survey research is a research collecting data through sample asked by using questionnaire and interview with the result that it can infer sort of aspects from population (Faenkel \& Wallen, 1990). The respondents that were chosen by using purposive sampling of this study were EFL teachers whose criteria are teachers who have teaching experience at least 3 years. The total of them are 29 teachers. The researcher uses purposive sampling technique to choose his respondents. The teachers are divided into 10 EFL teachers of Elementary School, 10 EFL teachers of Junior High School and 9 EFL teachers of Senior High School. The researcher decides to take those teachers with the criteria because they are surely ever taught by using Media for many times. Beside interview, they were given a questionnaire by means of close-ended question and open-ended question.

\section{RESULTS AND DISCUSSION}

This section presents the analysis of data collected. It begins with the information of respondents from interview and questionnaire. The result of the data collection and analysis is explained as well as the interpretation. The explanations of each point were provided with Lickert scaled items to be rated. These were accompanied by open-ended question and close-ended question that could make not only respondent express their feelings for but also justify which ratings they chose. There are some points discussed in this research concerning EFL teachers' perception toward media usage in teaching English such as the application of ELT media in teaching English necessity, the significant criteria in selecting media and finding any difficulty during the media application, and the teachers' action for composition comparison of media usage in 2013 curriculum and software and hardware media.

\subsection{The Application of ELT Media in Teaching English Necessity}

There are two points becoming a result for this part such as being benefit for both teachers and students and being applicable for every class.

\section{Being Benefit for Both Teachers}

This result explained that media can be benefit for both teachers and students. It is gained from analysis data done by researchers from interview and questionnaire. There are three interviewees answering for this research's question. The first interviewee gives an explanation supporting this result that with media usage in my English class, she can deliver the material as good as she can. For controlling and handling the class, it is easier for me. Every single medium that she uses is really helpful. For the students, not to mention about the appropriate teaching strategy, of course, media become something that can motivate them to actively participate in the class activities. The students are positively encouraged in getting involved and learning the given material. The explanation of the first interviewee above concludes that media can help the teacher in teaching. When she feels easier to control and handle the class. 
IJOTL TL, Vol. 5, No. 1, January 2020

p ISSN: 2502 2326; e ISSN: 2502 8278

Https://soloclcs.org; Email: ijolt1@gmail.com

Center of Language and Cultural Studies, Surakarta, Indonesia

Madayani, Soengkono, Nany \& Muhassin. 2020. Exploring Perception of EFL Teachers

towards the Use of Media in Teaching English.

IJOTL TL (2020), 5(1): 29 44. DOI: 10.30957/ijotl fl.v5i1.613.

The students taught by the teacher become motivated to actively to join the class activity.

The explanation of the second interviewee also supports this finding. He explains that for him as the teacher, Media is effective to gain the achievement of learning target well. He really proposes to apply ELT media, but the application should be in line with the creativity of adopting teaching strategy. It becomes useless if the teacher has various good media such as the facility from school or borrowing the friends' media but is fail in delivering the strategy. It will be useless for students in getting benefit from the media. The explanation of the second interviewee above concludes that media has to collaborate with the creativity of teachers' strategy to give the advantages for students in studying the material. The more the students can get the maximal achievement, the more the teachers have the strategy creativity of media usage.

The third interviewee gives explanation that media are really advantageous in English language teaching. Based on my personal experience, for instance, there is a big difference between my media applied class with the one that does not include media. Her class becomes livelier once she uses media. The students participate more actively in the learning process as well. The students can understand and practice the lesson easily although the lesson needs to think hard. She is as the teacher also can deliver my material without wasting much time and power. The explanation above concludes that Media becomes benefit tools for teachers and students in class activity. The difficult lesson or material can be easier to be understood by the students and the teachers that also are able to deliver the material without wasting much time. To support the result of the data above, the researcher spread questionnaires with some statements. The researcher gives the criteria for percentage by using percentage and classification. The result shows that the statement of whether media has an advantage in helping teachers to convey the teaching material is $88,9 \%$. The result shows that most of the teachers know that media can be useful for assisting them in presenting teaching material to the students. The next statement is about whether Media can be used to enhance the aspects of language (practice). The percentage of this statement is $88,9 \%$. That means that most of them agree that the students automatically gains better result in practicing the language aspects when media are included in the activity. The next statement has percentage $85,2 \%$. That means most of the teachers also have good understanding that media can be helpful for enhancing the students' language aspect production.

\section{Being Applicable for Every Class.}

This result explained that various media can be applicable for every class in teaching learning English as long as the teachers need to use it with suitable material. It is gained from analysis data done by researchers from interview and questionnaire. There are three interviewees answering for this research's question. The first interviewee gives an explanation supporting this result that she usually applies media in all of my English class, even if the media is the simplest tool. But there are certain activities that are so suitable. The example is for Listening and Speaking. These two 
IJOTL TL, Vol. 5, No. 1, January 2020

p ISSN: 2502 2326; e ISSN: 2502 8278

Https://soloclcs.org; Email: ijolt1@gmail.com

Center of Language and Cultural Studies, Surakarta, Indonesia

Madayani, Soengkono, Nany \& Muhassin. 2020. Exploring Perception of EFL Teachers

towards the Use of Media in Teaching English.

IJOTL TL (2020), 5(1): 29 44. DOI: 10.30957/ijotl tl.v5i1.613.

skills are needed by using native speaker sound so that the students can identify the authentic example of how to speak in a good intonation, stress and pronunciation. The quoted interview says that every class can be taught by using Media. The interviewee says that Media is the simplest tool to help the activity class run well. English has four skills such as speaking, reading, listening and writing. But the most essential skill that needs media is speaking and listening. Those skills can't be practiced well except native. Because of that, the first interviewee above says that speaking and listening are so suitable for the existence of media in action.

The second interviewee also gives explanation actually that he uses media in teaching English in the class rarely. He uses media when in emergency situation. It is like when he fells difficult to make students understand the material and the students have bad mood on track. Because of that, he uses media when the material based on experience needs media to help students understand it although the media generally can be used in every skill and class. Besides that, He uses media to keep the students' mood on the track. The quoted interview says that the interviewee uses media rarely in teaching English. The reason is because the interviewee doesn't always need media to help him in teaching English. He uses the media when he needs only such as emergency situation for students' difficult understanding and keeping the students' mood track.

The third interviewee gives close mutual explanation like the interviewee before that she totally understands that various media are applicable in various English language teaching, from the simplest to the sophisticated ones. However, she personally utilizes media rarely in my English class, especially ongoing semester because of some consideration. However, she really uses media if she has enough time to prepare it, looking for the ones which suitable with the activities that she plans to have in the classroom, and of course she needs media assistance to make his students stay focused in what they learn without getting bored. The quoted interview concludes that media can be used in every skill in English. Using media for teaching activity in class needs immolation for the teachers. The teachers have to prepare it and have to keep a close watch on suitable media that can be used for the material and target besides wasting students' bored feeling.

\section{The Significant Criteria in Selecting Media and Finding Any Difficulty during the Media Application.}

The researcher, in this part, focuses to know the teachers' outlook of media after the teachers apply in their English class. Thus, the researcher especially wants to dig the data based on the experience of teachers' in applying the media.

\section{Concerning With the Media Mastery and Media Flexibility.}

The answer of these interviewees explains that significant criteria in selecting media depend on mastery of teachers in media and the suitable media with the objective of teaching. The first interviewee gives explanation based on the experience about the outlook of media usage that the media can efficiently help her to achieve the teaching target. In presenting the material in the class, she really concerns with the flexibility of 
IJOTL TL, Vol. 5, No. 1, January 2020

p ISSN: 2502 2326; e ISSN: 2502 8278

Https://soloclcs.org; Email: ijolt1@gmail.com

Center of Language and Cultural Studies, Surakarta, Indonesia

Madayani, Soengkono, Nany \& Muhassin. 2020. Exploring Perception of EFL Teachers

towards the Use of Media in Teaching English.

IJOTL TL (2020), 5(1): 29 44. DOI: 10.30957/ijotl tl.v5i1.613.

the media that she makes by herself although her school prepares the language laboratory. But it cannot be used for some reason. That is one of my difficulties with media prepared by school. Sometimes she feels those are not suitable with her material and her purpose. Due to that, she only uses media that she really familiars with and master to. The quoted interview concludes that the school serves some media to be used for teachers. The interviewee knows that the medium is able to assist her in teaching activity in the class. But not whole of media can work well like what the teachers hope and master in teaching English. Because of that, the teachers prefer to use the private media made by teachers themselves.

The second interviewee also replies the question with almost mutual answers that he doesn't have special significant media to select the teaching media. He only applies media that is suitable with the context of his teaching material although the media generally can be operated for each skill. He also prefers to use media that he really masters to, with the hardware that he is really able to operate. The quoted interview concludes that media can be used for each skill in teaching English but not every material can be suitable with the material. Selecting media to be used in class is not easy although the media is served by school. The interviewee says that the better media to be applied in teaching learning English is Media mastered by the teacher himself.

The third interviewee adds explanation that the significant criteria of media to be selected by her are easy for preparation, simple to be made, and enjoyable in practice. She also prefers to use media that can be supported by less error hardware media, whether it is about the electricity or internet connection. Sometimes the media that used electricity or internet connection gives her some difficulties although the media surely is modern tools. The quoted interview concludes that most preferred media to be selected in teaching English is simple to create it, enjoyable to practice it and less error in practice.

\section{Being Different Students' Reference and Less Facility}

The next question which is asked to the interviewees is what kind of the teachers' difficulty during media application in the English language teaching. The context of teaching process here covers presenting material, facilitating the students to identify linguistic aspects and encouraging the students to produce linguistic aspects. Each of the interviewee has little different opinion about this matter but the main point is mutual. The first interviewee gives explanation that once again she has to say, the current unavailability of language laboratory forces to have listening section and the other activity that require sound system support in the classroom. It indeed eventually cannot be maximized since she has to consider the other running classes. Besides, she has so many media that need supporting hardware media which are not so handy to be mobilized. The quoted interview above shows that not whole school has language laboratory. Language laboratory is made to improve deeply about the English aspect especially for listening or speaking. These skills have to use language laboratory for media application. Unfortunately the laboratory language can't be used well so that the 
IJOTL TL, Vol. 5, No. 1, January 2020

p ISSN: 2502 2326; e ISSN: 2502 8278

Https://soloclcs.org; Email: ijolt1@gmail.com

Center of Language and Cultural Studies, Surakarta, Indonesia

Madayani, Soengkono, Nany \& Muhassin. 2020. Exploring Perception of EFL Teachers

towards the Use of Media in Teaching English.

IJOTL TL (2020), 5(1): 29 44. DOI: 10.30957/ijotl fl.v5i1.613.

practice of listening media such as audio, video etc. has to be done in class. it will bother the other class in concentration of learning.

The second interviewee also gives explanation that for particular media like song, the students are sometimes not really attracted for they feel that is not - their song\|, in other word the song does not sound good. Students' interest toward song or film is relatively different. That is why it becomes another duty for him to motivate them to actively participate in the discussion. Another difficulty is the time constraint. He needs time to prepare media that will be delivered in his English class. In addition, some media also need extra time to be explored in the classroom. The quoted interview above concludes that different reference of each student is complicated problem. It is difficult to make media suitable for each student based on the students' interest. Time constraint is also one of obstacles in media application. Using media before teaching adds an extra time for the teacher to prepare it before coming in the class and an extra time to be done in the classroom.

The third interviewee also gives explanations that as she said before, the problem is the error that sometimes happens especially when we have film or video. It more or less distracts the students' focus in the classroom and it indeed wasting time. The other difficulty is more about the students. They do pay attention and show their enthusiasm when she uses media in presenting the material, but unfortunately they are not motivated enough to actively participate to the other activities like practicing or doing some tasks. Some important points can be selected to draw the conclusion of this result. The interviewees as English teachers do have some criteria in deciding to be assisted by media for the English language teaching. It is done to avoid the possibility of problem faced during the teaching and learning process. First, definitely the interviewees only use media that potentially helpful in achieving teaching goals. The media should be enjoyable, not ones that make the students get bored. The flexibility also is one of the considerations in applying media in the classroom including the mobility and error possibility. The teachers themselves have to be really familiar with the media.

To support the result of the data above, the researcher spread questionnaires with some statements. The researcher gives the criteria for percentage by using percentage and classification. The Statements are especially asked to examine the teacher outlook about the role of media in assisting teaching learning activity based on his/ her personal experience so far. Statement number 10 asked whether Media is an interesting helping-tool to be used in teaching learning activity. The percentage of this statement is $77,8 \%$. It means, most of the teachers agree with the statement. The next statement which is statement number 11 asked whether media applicable to the teacher $\mathrm{him} /$ herself English class. The percentage for this statement is $70,42 \%$. Undoubtedly, the percentage shows that most of the teachers totally agree with the statement. Meanwhile, the last statement of this group which is question number 15 asked whether my activity of teaching learning in the class runs well with the existence of media. The result shows that most of the teachers have very good outlook toward this statement. It can be seen from the achieved percentage which is $77,8 \%$. 
IJOTL TL, Vol. 5, No. 1, January 2020

p ISSN: 2502 2326; e ISSN: 2502 8278

Https://soloclcs.org; Email: ijolt1@gmail.com

Center of Language and Cultural Studies, Surakarta, Indonesia

Madayani, Soengkono, Nany \& Muhassin. 2020. Exploring Perception of EFL Teachers

towards the Use of Media in Teaching English.

IJOTL TL (2020), 5(1): 29 44. DOI: 10.30957/ijotl fl.v5i1.613.

The next three statements respectively are provided to reveal the teacher outlook about the role of media for him/ herself as an English teacher. The first Statement is asking whether the teachers feel more confident when teaching by using media. The percentage of this statement is $85,2 \%$ which is classified as a very good view. The next statement asked about the effectiveness and efficiency concern of media in assisting the teacher to present the teaching material. The percentage for this statement is $88,9 \%$ which means most of the teachers have a positive view of the statement. The last statement of this group which is statement number 14 deals with the ability of media in assisting the teacher to reach his/ her teaching target. The result shows a positive response. It can be seen from the percentage which is $74,1 \%$.

The last three statements aimed at investigating the teachers' outlook about the role of media specifically for the students of English language teaching. The statement is asking whether it is more comprehensible when the teacher uses media to deliver the material. The percentage for this statement is $88,9 \%$. It shows that most of the teachers have a very good outlook toward this statement. Revealing the information about teachers' outlooks about the role of media in assisting the students to recognize linguistic aspect is the objective of next statement. The percentage for this statement is $85,2 \%$. Next Statement however, asked whether media can situate a better learning process for producing linguistic aspects activity. Same as the previous statement, the percentage of this statement is $88,9 \%$, which shows that most of the teachers have a good outlook toward the statement. The elaboration above reveals that all of the statements are responded in a positive way.

\section{The Teachers' Action for Composition Comparison of Media Usage in 2013 Curriculum and Software and Hardware Media}

There are two parts of result in this part. The first part is from teachers' action in using software media and hardware. This part is taken by using questionnaire and interview. The second part is about teachers' action of composition comparison toward media usage in 2013 curriculum. This part is the result of interview that aims to dig up the information toward ELT media especially about teacher action. The question here is about the composition comparison of media usage when it is implemented in 2013 curriculum.

\section{Observing in Most Applying Media}

There are five approaches in teaching and learning process applied in 2013 curriculum. Those are observing, questioning, questioning, associating, experimenting, and communicating. The three interviewees have similar answers for the question. They mostly use media for the first stage of teaching and learning activity. The first interview said that she applies media mostly in observing and questioning activity. It aims to bring the students to my teaching track. she also uses media to highlight what has been learned in the classroom at the end of the class meeting. It is kind of making conclusion together with the student which usually is done visually by using Microsoft power point program. 
IJOTL TL, Vol. 5, No. 1, January 2020

p ISSN: 2502 2326; e ISSN: 2502 8278

Https://soloclcs.org; Email: ijolt1@gmail.com

Center of Language and Cultural Studies, Surakarta, Indonesia

Madayani, Soengkono, Nany \& Muhassin. 2020. Exploring Perception of EFL Teachers

towards the Use of Media in Teaching English.

IJOTL TL (2020), 5(1): 29 44. DOI: 10.30957/ijotl fl.v5i1.613.

The second interview said that for him, media are mostly applicable in the beginning activity. Media especially help him to build the students' mood to be ready to learn English. Media are also useful to introduce what will be learned. The third interviewee said that So far, I use media $75 \%$ at the beginning of the activity as let us say warm up activity. It is really helpful in getting the students attention. Based on the identification of answers above, those three interviewees mostly apply media on the first stage from five approaches promoted by 2013. However, it doesn't mean that the media has to be applied in first stage only.

\section{Software and Hardware Media in Action}

In this particular investigation, the researcher provides 10 software items which belong to three different groups of media which are classified based on the sensory channels. There are four audio media, three visual media and three audio visual media which relevant in English language teaching. The researcher then tried to investigate how these ten media are used in different comprehension aspects which are promoted in English language teaching. The skills cover listening, speaking reading and speaking. This is to reveal the frequency of using the media, whether there are some media which frequently used at all. Thus, differently, from previous two questionnaires which adapted Likert-scale questionnaire, the researcher still used the Google form to measure the percentage of never scale.

\section{Listening}

Result shows that the teachers' action is quite different from one to the other media. There are some media that used frequently in enhancing the students listening comprehension, but there are also some media that are not frequently used. It can be seen from the percentage of each of the media as well as the classification. Based on the measurement percentage of never scale above, Audio recording is one of the most frequently used in enhancing the students listening skills. The percentage of this particular software is $11,1 \%$. It is followed by song which percentage's is $40,7 \%$. Both of the software is classified as media with a positive classification or very good and good response, which mean most of the teachers have a very good action toward audio recording and song.

The other media which have good response from most of the teachers are video (documentary, tutorial and lecture) and film (drama, fairy tale and biography) which percentage $33,3 \%$ and $25,9 \%$. These results show that most of the teachers have a good action toward these two media, or it can be said that these media are also frequently used in enhancing the students' listening skills. On the other hand, there are some media that seemed not to be frequently used in improving the students' listening skill such as audio drama and picture. The percentage for audio drama software is $51,9 \%$ while picture's is $55,6 \%$. That means most of the teachers have a bad response toward two software of media. In addition, the rest of the media presented in the table such as news repost, flash card, chart and TV program are also classified in a group of software media which are not frequently used by the teachers. It can be seen from each of 
IJOTL TL, Vol. 5, No. 1, January 2020

p ISSN: 2502 2326; e ISSN: 2502 8278

Https://soloclcs.org; Email: ijolt1@gmail.com

Center of Language and Cultural Studies, Surakarta, Indonesia

Madayani, Soengkono, Nany \& Muhassin. 2020. Exploring Perception of EFL Teachers

towards the Use of Media in Teaching English.

IJOTL TL (2020), 5(1): 29 44. DOI: 10.30957/ijotl tl.v5i1.613.

percentage and classification, 51,9 \% for news report; 55,6 \% for flash card; 59,3\% for chart; and $70,4 \%$ for TV program.

\section{Speaking}

There are three of ten software which have a good response from the teachers while the rest of them have bad and very bad response. One representative of each media classification which are audio recording, picture and video are classified as media which are frequently used by the teachers. It can be seen by the disagreement percentage of those three media, respectively $25,9 \%, 29,6 \%$ and $37 \%$. That means most of the teachers have a good action toward audio recording, picture and video when the objective of teaching deals with the students' speaking skills.

\section{Reading}

There is only one medium which is seemed to be frequently used by the teachers in improving the students' reading skill. The result reveals that picture is the teachers' favourite assistant to enhance the students' reading skills. It can be seen from its disagreement percentage which is merely $11,1 \%$ and it means most of the teachers have a good action toward that particular medium. While the rest of the media and their percentage, respectively audio recording; $70,4 \%$, audio drama $59 \%$, news report $61,5 \%$, song $55,6 \%$, flash card 59,3\%, chart 51,9\%, video 66,7\%, film 55,6\%, and TV program $70,4 \%$ got a negative response form the teachers. It means most of the teachers do not have a good action toward those media in dealing with improving the students' reading skills.

\section{Writing}

The data collection result reveals that ten media proposed by the researcher are used by the teachers in a quite different frequency. Similar to reading skill, most of the teachers also have a positive action toward picture in enhancing the students' writing skills. It is proved by the fact that picture gets the least disagreement percentage which is $14,8 \%$. Most of the teachers also have a positive response toward flash card for its percentage is $37 \%$. That means most of the teachers have a good action toward flash card. The other 8 media are not frequently used by most of the teachers in dealing with students' writing development. It can be seen by the percentages of six media that included in bad response category such as audio recording; $61,5 \%$, audio drama $59 \%$, song $70,4 \%$, chart $55,6 \%$, video $66,7 \%$, and TV program $70,4 \%$. These media are the followed by news report and TV program which are also categorized as not frequently used media for the percentages are $63 \%$ and $70,4 \%$.

The next section of spreading questionnaire is about hardware. This is presented to reveal the secondary data which are used to support and enrich the main data of teachers' action toward ELT media. As each of the media presented in the previous section needs hardware to be delivered in the classroom, this particular section will especially present teachers' action toward hardware media. It aims at investigating the teacher's choice of the hardware that assists him/ her in in English language teaching. The hardware media are classified based on the sensory channels from the 
IJOTL TL, Vol. 5, No. 1, January 2020

p ISSN: 2502 2326; e ISSN: 2502 8278

Https://soloclcs.org; Email: ijolt1@gmail.com

Center of Language and Cultural Studies, Surakarta, Indonesia

Madayani, Soengkono, Nany \& Muhassin. 2020. Exploring Perception of EFL Teachers

towards the Use of Media in Teaching English.

IJOTL TL (2020), 5(1): 29 44. DOI: 10.30957/ijotl tl.v5i1.613.

simple to the sophisticated one. Audio media include radio, tape, CD player, smartphone and computer. Meanwhile, visual media include paper, class board, printed paper, and computer. The last one audio-visual medium includes Television, VCD player, DVD player, and computer.

For Audio, There is only two of five hardware proposed by the researcher which gets good response from most of the teachers. The result shows that most of the teachers have a good action toward computer and smart phone in delivering audio software ELT media. The percentage of this particular media is $14,8 \%$ and $11,1 \%$, which is the highest percentage for this hardware group. Meanwhile, the rest of the media such as tape, CD player and radio are not frequently utilized by the teachers, for the percentages of those media classified as both bad and very bad response.

For Visual, The result shows that the teachers have good action toward the hardware. The least percentage held by computer which is $0 \%$. It means most of the teachers utilize computer in delivering visual software media. It is followed by the other three hardware namely paper, class board and printed paper which are percentage respectively $37 \%, 29,6 \%$ and $25,9 \%$.

For Audio-Visual, Almost similar to the audio group, most of the teachers have a very good response to one particular media which is the computer. It can be seen that it percentages $0 \%$ which makes the computer is the prior hardware which is used to deliver audio-visual media in the classroom.

The rest of the hardware is still used in the classroom by the teacher but not as frequently as computer. As revealed in the table, the percentage of VCD player is $66,7 \%$, which categorized as bad response. It is followed by the other three hardware sequentially DVD player, television and smart TV which including in bad response group. It means most of the teachers do not have a good action toward those hardware media.

\section{CONCLUSION}

The teachers shared that they realise English language teaching will be done effectively if they are assisted by other supporting system including media. It is also revealed that the teachers are familiar with media which is applicable in English language teaching. The experience of utilizing media in their English class influences the teachers' outlook of ELT media. They admitted that utilizing media with suitable teaching strategy can bring various advantages for both teachers and students. The teachers also shared that having a good preparation, mastering the media that will be presented in the classroom and recognizing the students' needs indeed help them in maximizing the benefit of media in their English class. For this point, some students generally don't know more about the benefit of media in obtaining good achievement. They don't realize that the teachers are trying to improve the students' skill by using fun enjoyable media.

However, having good understanding and outlooks are not eventually followed by good media application. The result shows that most of the teachers only rely on certain media especially in enhancing the students' language comprehension such as 
IJOTL TL, Vol. 5, No. 1, January 2020

p ISSN: 2502 2326; e -ISSN: 2502 8278

Https://soloclcs.org; Email: ijolt1@gmail.com

Center of Language and Cultural Studies, Surakarta, Indonesia

Madayani, Soengkono, Nany \& Muhassin. 2020. Exploring Perception of EFL Teachers

towards the Use of Media in Teaching English.

IJOTL TL (2020), 5(1): 29 44. DOI: 10.30957/ijotl tl.v5i1.613.

listening, speaking, reading and writing. Each of the teachers has his/ her own consideration in deciding his/ her media choice. Some of the considerations revealed through this study are, the time constraint in preparing the appropriate media, lack of knowledge in developing suitable teaching strategy as well as limitation of technical supporting system.

The data analysis result shows that the teachers have good understanding of media as the average score of their understanding is $75 \%$. The teachers shared that they have very good outlook of ELT media as well; it is proved by the average score of their view which is $81,91 \%$. The result reveals that English teachers have good perceptions of ELT media. Additionally, the teachers are now already familiar with the use of digital hardware media. Most of them prefer to use digital media for the quality and effectiveness concern, although there are also some teachers who still frequently apply traditional hardware media in the classroom.

\section{REFERENCES}

Ali, M. (2009). Pengembangan media pembelajaran interaktif mata kuliah medan elektromagnetik. Jurnal Pendidikan Teknik Elektro FT UNY. Vol. V (No. 1).

Amelia, R. (2015). Traditional media still exist in digital era: maximizing pictures in TEFL. English language education study program of Sanata Dharma University (pp. 241-248). Yogyakarta: English language education study program of Sanata Dharma University.

Ary, D., Jacobs, L. C., \&Razavieh, A. (2002). Intorduction to research in education. New York: Wardsworth Thomson Learning.

Atkinson, R., \& Hilgard, E. R. (1999). Pengantarpsikologi. Jakarta: Erlangga.

Bellani, S. (2011, May 21st). The advantages of using flashcard in learning. Retrieved May 2nd, 2016, from Ezine Articles:

Boore, G. C. (2012, December 8th). Perception and interaction. Shippenburg, Pennsylvania, USA. Retrieved from Discover psychology.

Bradley, B. (2002). Psychology and experience. Cambridge: Cambridge University Press.

Brown, H. D. (2000). Principles of Language and Teaching. New York: Addison Wesley Longman, Inc.

Chan, W. M., Chin, K. N., Nagami, M., \&Suthiwan, T. (2011). Media in foreign language teaching and learning. Chicago: Walter de Gruyter. [12]Chaplin, J. P. (1968). Dictionary of psychology. New York: Dell Publishing Co. Inc.

Clark, R. E. (1994). Media will never influence learning. Boston: Heinle \& Heinle.

Corporation for Public Broadcasting. (2004). Television goes to school: the impact of video evaluation.

Dale, E. (1969). Audiovisual method in teaching. New York: The Dryden Press.

Danil, D. Upaya Profesionalisme Guru Dalam Meningkatkan Prestasi Siswa di Sekolah (Study Deskriptif Lapangan di Sekolah Madrasah Aliyah Cilawu Garut). Vol. 03; No. 01; 2009; 30-40. 
IJOTL TL, Vol. 5, No. 1, January 2020

p ISSN: 2502 2326; e -ISSN: 2502 8278

Https://soloclcs.org; Email: ijolt1@gmail.com

Center of Language and Cultural Studies, Surakarta, Indonesia

Madayani, Soengkono, Nany \& Muhassin. 2020. Exploring Perception of EFL Teachers

towards the Use of Media in Teaching English.

IJOTL TL (2020), 5(1): 29 44. DOI: $10.30957 /$ ijotl tl.v5i1.613.

Dretske, F. (1988). Explaining behavior. Cambridge, MA: MIT Press.

Dwijatmoko, B. B. (2015). Indonesian English teachers' readiness for ICT use. Teaching and Assessing L2 Learners in the 21st Century (pp. 686-693). Denpasar: Faculty of Letters and Culture, Udayana University.

Eunice Rugut and Jesse Role. (2013). Teachers and Students Perceptions on the Utilisation of Educational Media in Teaching and Learning History and Government in Secondary Schools in Kenya. International Journal of Science and Research (IJSR) ISSN (Online): 2319-7064 Index Copernicus Value

Fachrurrazy. (2011). Teaching English as a foreign language for teachers in Indonesia. Malang: State University of Malang Press.

Hamalik, O. (1994). Media Pendidikan. Bandung: PT. Aditya Bakti.

Hambrook, J. (1979). Television materials for ELT. In T. B. Council, The use of media in English language teaching (pp. 24-30). London: The British Council Printing and Publishing Department.

Harmer, J. (2001). The practice of English language teaching. Harlow: Pearson Education.

Harmer, J. (2007). How to teach English. Essex: Pearson Education Limited.

Harsono, Y. M. (2006). English language teaching in Indonesia: facts, problems and possible solution. English education journal, 5 (2).

Heinich, R., Molenda, M., \& Russell, J. D. (1982). Instructional media and the new technologies of instruction. New York: John Wiley \& Sons.

Howse, H. (1979). BBC English by radio and television: an outline history. In T. B. Counsil, The use of media in English language teaching (pp. 15-23). London: The British Counsil Printing and Publishing Department. Ip, Y. K. (2003). Knowing is not the same as understanding: what is understanding? Retrieved December 8th, 2012, from Successful Learning: http://www.cdtl.nus.edu.sg/success/s120.htm http://ezinearticles.com/?The-Advantages-of-Using-Flashcards-inLearning\&id $=6288984$

Ismaili, M. (2013). The effectiveness of using films in the EFL classroom: a study conducted at South East European University. Academic Journal of Interdisciplinary Studies, 121-132.

Kabooha, R. H. (2016). Using films in EFL classroom: a study conducted at the English Language Institute (ELI). Journal of English Language Teaching, Vol. IX (No. 3), 248-257.

Kachru, B. B. (1992). The Other Tongue: English across cultures. Urbana: University of Illionis Press.

Kasihani, K. E. (2000). Pengembangan kurikulum Bahasa di Indonesia. The National Convention of Indonesia Education, 19-22.

Königs, F. G. (1999). To know English or not to knw English. Tumbingen: Stauffenburg Verlag. 
IJOTL TL, Vol. 5, No. 1, January 2020

p ISSN: 2502 2326; e ISSN: 2502 8278

Https://soloclcs.org; Email: ijolt1@gmail.com

Center of Language and Cultural Studies, Surakarta, Indonesia

Madayani, Soengkono, Nany \& Muhassin. 2020. Exploring Perception of EFL Teachers

towards the Use of Media in Teaching English.

IJOTL TL (2020), 5(1): 29 44. DOI: 10.30957/ijotl tl.v5i1.613.

Lodico, M. G., Spaulding, D. T., \&Voegtle, K. H. (2006). Method in educational research. San Fransisco: Jossey-Bass.

Mardapi, D. (2008). Teknik penyusunan instrument tes dan nontes. Yogyakarta: Mitra Cendekia Press.

McNamara, J. F. (1994). Survey and Experiments in education research. Lancaster PA: Technomic Publishing.

Morris, B. (1962). The function of media in the public schools. Audiovisual Instruction, 8 (9), 9-14.

Munadi, Y. (2010). Media Pembelajaran; Sebuah Pendekatan Baru. Jakarta: Gaung Persada Press.

Murphey, T. (1992). Music and Song. Oxford: Oxford University Press.

Newby, T. J., Stepich, D. A., Lehman, J. D., \& Russel, J. D. (1996). Instructional technology for teaching and learning: designing instruction, integrating computers, and using media. Upper Saddle River: Pearson Education.

Pun, M. (2013). The use of multimedia technology in English language teaching: a global perspective. International Journal of Interdisciplinary Studies, 29-38.

Ramsey, F. H. (1986). The little brown handbook. Boston: Little Brown.

Rao, B. M. (2014). Use of media as an instructional tool in English Language Teaching at undergraduate level. International Journal of English and Literature, Vol. V (No. 6), 141-143.

Riduan. (2009). Dasar-Dasar Statisktika. Bandung: Alfabeta.

Romiszowski, A.J. (1998). The Selection and use of Instructional Media. London: Kogan Page.

Sadiman, A. S., Rahardjo, R., Haryono, A., \& Rahardjito. (2009). Media pendidikan: pengertian, pengembangkan, dan pemanfaatannya. Jakarta: Rajawali Press.

Sedarmayanti (2001). Audio visual media and English learners. International journal on recent and innovation trends in computing and communication, Vo. 2 (No. 2), 384-386.

Silcha, W. N., \&Ivone, F. M. (2015). Using facebook with process writing strategy to enhance the teaching of recount text. English Language Education Study Program Sanata Dharma University (pp. 391-399). Yogyakarta: English Language Education Study Program Sanata Dharma University.

Smaldino, S. E., Lowther, D. L., \& Russell, J. D. (1996). Instructional technology and media for learning. Boston: Pearson Education Inc.

Soedijarto (1991) Media pembelajaran interaktif-inovatif. Yogyakarta: Kaukaba Dipantara.

Soko (2017). Using English songs: an enjoyable and effective approach to ELT. CCSE English Language Teaching Journal, 88-94.

Stewart, D. M. (2006). Film English: using film to teach English. Electronis Journal of English Education, 1-17.

Sukidjo (2003). English for young learners. Jakarta: PT. BumiAksara. 
IJOTL TL, Vol. 5, No. 1, January 2020

p ISSN: 2502 2326; e ISSN: 2502 8278

Https://soloclcs.org; Email: ijolt1@gmail.com

Center of Language and Cultural Studies, Surakarta, Indonesia

Madayani, Soengkono, Nany \& Muhassin. 2020. Exploring Perception of EFL Teachers

towards the Use of Media in Teaching English.

IJOTL TL (2020), 5(1): 29 44. DOI: $10.30957 /$ ijotl tl.v5i1.613.

Tafani, V. (2009). Teaching English through mass media. Acta Didactica Napocensia, Vol. 2 (No. 1), 81-96.

Taiwo, S (2002). Teachers' perception of the role of media in classroom teaching in secondary schools. in Turkish Online Journal of Educational Technology.

Tomalin, B. (1979). Using BBC English by radio and television in the classroom. In T. B. Council, The use of media in English language teaching (pp. 68- 74). London: The British Council Printing and Publishing Department.

Tschirner, E. (2011). Video clips, input processing and language learning. In W. M. Chan, K. N. Chin, T. Suthiwan, \& M. Nagami, Media in foreign language teaching and learning (pp. 25-40). Berlin: De Gruyter Mouton.

Usman Uzer, 1998. Menjadi Guru Fropesional. Bandung: RemajaRosdakarya.

Vernon, M. D. (1987). The psychology of perception. Middlesex: Penguin Books.

Wang, Y., \& Zhang, H. F. (2012). The application of English films in higher vocational English teaching. Journal of Sino-US English Teaching, 1010- 1014.

Wells, G. (1987, March). Apprenticeship in Literacy. Interchange, pp. 109-123.

Wiersma, W. (1995). Research method in Education: an introduction. New York: Allyn and Bacon.

Wigginss, G. (1998). Educative assessment. San Fransisco: Jossey-Bass Publisher.

Wilson, G. (2012, April 4th). Action. Retrieved October 17, 2012, from Stanford encyclopedia of philosophy: https://plato.stanford.edu/entries/action/

Woolfolk, A. E. (1998). Educational psychology. Boston: Allyn\& Bacon. 
IJOTL TL, Vol. 5, No. 1, January 2020

p ISSN: 2502 2326; e ISSN: 2502 8278

Https://soloclcs.org; Email: ijolt1@gmail.com

Center of Language and Cultural Studies, Surakarta, Indonesia

Madayani, Soengkono, Nany \& Muhassin. 2020. Exploring Perception of EFL Teachers

towards the Use of Media in Teaching English.

IJOTL TL (2020), 5(1): 29 44. DOI: 10.30957/ijotl tl.v5i1.613. 